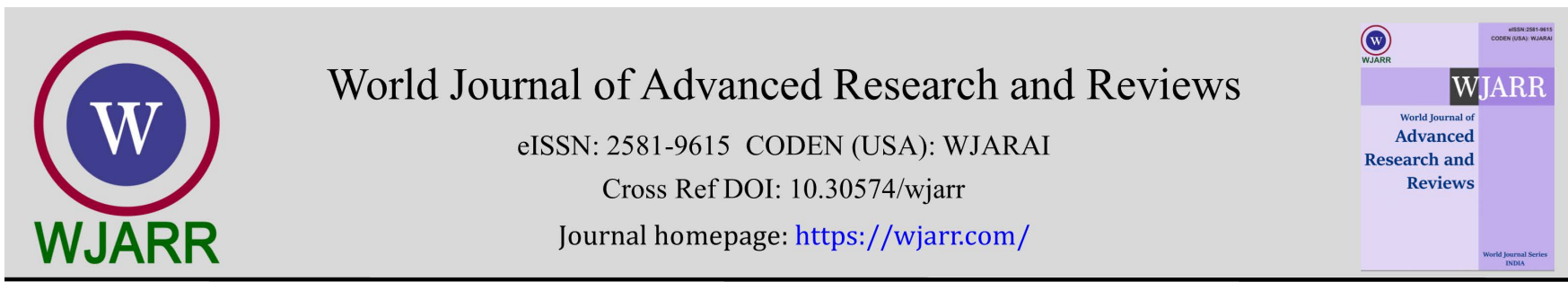

(RESEARCH ARTICLE)

Check for updates

\title{
Analysis of ßeta-carotene from Jongi (Dillenia Serrata Thunb.) as a source of vitamin A
}

\author{
Khairun Nisa ${ }^{1}$ and Ryka Marina Walanda ${ }^{2, *}$ \\ ${ }^{1}$ Department of Chemistry Education, Faculty of Education, Tadulako University, Palu 94118 - Indonesia. \\ 2 Department of Biochemistry, Faculty of Medicine, Tadulako University, Palu 94118, Indonesia.
}

World Journal of Advanced Research and Reviews, 2021, 10(02), 184-190

Publication history: Received on 27 March 2021; revised on 01 May 2021; accepted on 04 May 2021

Article DOI: https://doi.org/10.30574/wjarr.2021.10.2.0195

\begin{abstract}
Beta-carotene is converted in the body to vitamin A, a powerful antioxidant that plays an essential role in maintaining healthy eyes, skin, and neurological function. Beta-carotene and other carotenoids have antioxidant activities and are valued for their ability to prevent chronic disease. $\beta$-carotene is found in yellow, orange, red, and green fruits. The purpose of this study was to determine the $\beta$-carotene in Jongi. Jongi (Dillenia Serrata Thunb.) is an endemic fruit of Sulawesi which contains $\beta$-carotene. The samples used in this study were raw jongi and ripe jongi extracted with nhexane: acetone (1:4). To the samples were analyzed quantitatively using UV-Vis spectrophotometry at a wavelength of $450.00 \mathrm{~nm}$. The results showed that the $\beta$-carotene in raw jongi was $0.3554 \mathrm{mg} / 100 \mathrm{~g}$ and the $\beta$-carotene in ripe jongi was $1.1841 \mathrm{mg} / 100 \mathrm{~g}$. Ripe jongi consist of more $\beta$-carotene than the raw jongi, hence better as a source of Vitamin A.
\end{abstract}

Keywords: $\beta$-carotene; Jongi Fruit; UV-Vis Spectrophotometry.

\section{Introduction}

$\beta$-carotene is a substance found in various food ingredients, especially vegetables and fruits. This substance will be converted into vitamin A in the body. Because it will be converted into vitamin A, many people refer to this substance as vitamin $A$. In other words, $\beta$-carotene is a form of vitamin $A$ that has not been active, but when it is in the body, the body will naturally change it. This vitamin A will help all body functions to be optimal, from its function as an antioxidant to nutrition for the eyes [1]. $\beta$-carotene is a compound with vitamin A activity found in plants that are included in the carotenoid group. This carotenoid compound is a fat-soluble pigment [2]. In foods consumed, the most natural carotenoids found are $\beta$-carotene, $\alpha$-carotene, $\gamma$-carotene, lycopene, lutein, $\beta$-kryptoxanthin, zeaxanthin, and astaxanthin [3].

In the body, $\beta$-carotene has many other benefits: vision, cell differentiation, immunity, growth and development, reproduction, cancer prevention, heart disease, and many more functions of $\beta$-carotene [4]. $\beta$-carotenes a provitamin $\mathrm{A}$ with many benefits and is easy to obtain because $\beta$-carotenes found in many green, yellow, orange, and red fruits and vegetables [5]. This is also proven in research that has been done on red, yellow, and green peppers so that the highest $\beta$-carotene levels are found in red peppers, the second-highest $\beta$-carotene content is in yellow peppers, and $\beta$-carotene is the least in green peppers [6].

Several factors can influence the levels of vitamin $C$ and $\beta$-carotene: a) The condition of the fruit, where the fresher the fruit, the more vitamin $C$ and $\beta$-carotene levels in the fruit, b) Extraction time, the longer the sample is extracted, the lesser the content will be, c) The storage period, the longer the fruit is stored, the less the content in the fruit will be, d) The temperature, the higher the room temperature where the fruit is stored, the levels in the fruit are getting lower [7].

\footnotetext{
* Corresponding author: Ryka Marina Walanda

Department of Biochemistry, Faculty of Medicine, Tadulako University, Palu 94118, Indonesia.

Copyright (c) 2021 Author(s) retain the copyright of this article. This article is published under the terms of the Creative Commons Attribution Liscense 4.0.
} 
The recommended daily intake of vitamin A is $900 \mathrm{mcg}$ for men, $700 \mathrm{mcg}$ for women, and 300 - 600 mcg for children [8]. Daily vitamin A needs can be obtained from fruits such as mango, papaya, grapefruit, apricots, cantaloupe, watermelon, guava, etc. All of these fruits have been well done by the community. But many local fruits can only be found in certain areas which are also a source of vitamin A because they contain $\beta$-carotene, one of which is jongi.

Jongi plant (Dillenia Serrata Thunb.) is one of Sulawesi's endemic plants which is located in the Wallacean biographical sub-region, which is a transitional area between the Asian Continent and Australia, where one of them is in the Morowali regency, west Bungku Barat, Topogaro village [9]. Its sour taste makes jongi less attractive to the community. In contrast, in Topogaro village itself, this fruit is quite abundant. The fruit is wasted because it is not processed by the local community, even though this fruit can be processed into several food products such as sweet and candy [10].

The jongi plant has several benefits. Like other plants, this plant can be used to treat thrush, vomiting of blood, fever, and wound medicine. This plant contains several compounds, namely $\beta$-carotene, vitamin $C$, and citric acid, where one of the functions of $\beta$-carotene is as an antioxidant which can prevent the entry of free radicals into the body, vitamin $\mathrm{C}$ functions to maintain endurance and citric acid functions to accelerate the application of nutrition [11].

There are three physiological stages in the life cycle of the fruit, namely growth, ripening, and senescent [12]. The growth process involves cell division and is followed by cell enlargement, which is responsible for the maximum size of the cell. Ripening is a dramatic event in the life of fruit because it changes plant organs from physiologically ripe to edible fruit and is related to texture, taste, and aroma. Ripening is a particular term for the fruit which is an early stage towards aging. Senescent can be interpreted as a period towards aging and ultimately results in the death of the tissue [13].

Research related to jongi has been carried out, such as research on vitamin C and calcium levels and antioxidant activity tests based on their maturity level [14]. The study found that the highest levels of vitamin $C$ were in ripe jongi and the highest levels of calcium were in the matured through. However, there has been no research related to $\beta$-carotene levels in this fruit. Therefore, based on the above background, the study analyzed the $\beta$-carotene levels in jongi (Dillenia Serrata Thunb.) based on the level of fruit maturity using the UV-Vis spectrophotometric method. There have also been many studies on the analysis of $\beta$-carotene levels using this method, such as the analysis of carbohydrate, vitamin $C$, $\beta$ levels carotene, and iron in cherries using UV-Vis spectrophotometry [15]. The UV-Vis spectrophotometry was also uses when carried out on the analysis of $\beta$-carotene levels of plantain (Musa paradisiacal L.) and kepok banana (Musa paradisiaca forma typica) [16].

\section{Material and Methods}

\subsection{Research Methods}

The tools used in this study were UV-Vis spectrophotometry (Cecil), digital balance, centrifuge, blender, stirring rod, test tube, funnel, separating funnel, beaker, measuring cup, saucer, Erlenmeyer, measuring flask, dropper spatula, and petri dish. The materials used in this study were jongi fruit, acetone (Merck), distilled water, n-hexane solvent (Merck), pure $\beta$-carotene solid (Sigma), sodium chloride ( $\mathrm{NaCl}$ ) (Merck), anhydrous sodium sulfate $\left(\mathrm{Na}_{2} \mathrm{SO}_{4}\right)(\mathrm{Merck})$, butylhydroxytoluene (BHT) and filter paper.

There are three stages of work procedures in this study, namely:

\subsubsection{Sample Preparation}

Wash the jongi fruit thoroughly with water, then cut the sample, remove the seeds, and smooth the jongi using a blender and repeating the same treatment by replacing the sample using a sample of ripe jongi.

\subsubsection{Extraction Stage}

Weigh $0.019 \mathrm{~g}$ of butyl hydroxytoluene, then added to $100 \mathrm{~mL}$ of $\mathrm{n}$-hexane and acetone with a ratio of 1:4 into the weigh butylhydroxytoluene. Next, weigh $50 \mathrm{~g}$ of mashed jongi pulp and put it in the n-hexane solvent: acetone containing the previously prepared butyl hydroxytoluene. 


\subsubsection{Quantitative Analysis}

Preparation of the Mother Liquor $50 \mathrm{ppm} \beta$-carotene. Weighing pure $\beta$-carotene solid as much as $0.00125 \mathrm{~g}$, then dissolving it with $15 \mathrm{~mL}$ of $\mathrm{n}$-hexane into a $25 \mathrm{~mL}$ volumetric flask, sufficient the volume reaches $25 \mathrm{~mL}$, so that a solution with a concentration of 50 ppm obtained.

Extracting the sample using a centrifuge, separating the filtrate and residue after the extraction process at the centrifuge stops, then the residue is washed using the same solvent and extracted again, the extraction process is carried out three times. Next, mix the filtrate produced from the extraction process with $250 \mathrm{~mL}$ acetone into a separating funnel, add $250 \mathrm{~mL}$ of distilled water slowly to the separating funnel wall and add $2 \mathrm{~mL}$ of saturated NaCl. Performed shaking for \pm 30 minutes, allowed to stand the sample until two phases were formed, namely the n-hexane phase and the water phase. Remove the water phase from the separating funnel slowly. Then add $200 \mathrm{~mL}$ of distilled water and shake for \pm 30 minutes, repeat the same treatment up to 3 times. Next, remove the n-hexane phase from the separating funnel by filtering it using filter paper whose surface contains sufficient anhydrous sodium sulfate. Putting the filtrate obtained into a $25 \mathrm{~mL}$ volumetric flask, then add it with n-hexane until it reaches the limit mark. Repeating all the same treatments by replacing raw jongi fruit samples using ripe jongi, the next step is to measure the absorbance of each sample at a wavelength of $450 \mathrm{~nm}$.

\subsection{Calibration Curve Determination}

Making a standard solution of $\beta$-carotene with a concentration of $1 \mathrm{ppm}, 2 \mathrm{ppm}, 3 \mathrm{ppm}, 4 \mathrm{ppm}$, and 5 ppm by adding 0.2 $\mathrm{mL}, 0.4 \mathrm{~mL}, 0.6 \mathrm{~mL}, 0.8 \mathrm{~mL}$, and $1 \mathrm{~mL}$ of the $50 \mathrm{ppm}$ mother liquor that has been made into each measuring cup, then increase the volume with $\mathrm{n}$-hexane solvent to $10 \mathrm{~mL}$-measuring the absorbance of the standard solution that has been made using UV-Vis spectrophotometry at a wavelength of $450 \mathrm{~nm}$. In measuring, the sample blank solution used was nhexane solvent. The $\beta$-carotene content in the sample was determined based on a linear regression equation. Analysis of $\beta$-carotene levels is determined based on the linear regression equation.

$$
y=a+b x
$$

Where, $\mathrm{y}$ is the absorption and $\mathrm{x}$ is the concentration.

\section{Results and discussion}

Based on the research that has been done regarding the analysis of $\beta$-carotene levels in raw jongi and ripe jongi using UV-Visible spectrophotometric analysis, the following results were obtained.

Table 1 Data results $\beta$-carotene level analysis of raw jongi

\begin{tabular}{|c|c|c|}
\hline \multirow{2}{*}{ Raw jongi } & Until (mg/100 g) & Average rate(mg/100 g) \\
\hline \multirow{3}{*}{ Raw jongi } & 0.3564 & \\
\cline { 2 - 2 } & 0.3542 & \multirow{2}{*}{0.3554} \\
\cline { 2 - 2 } & 0.3556 & \\
\hline
\end{tabular}

$\beta$-carotene levels in the first analysis of raw jongi fruit were $0.3564 \mathrm{mg} / 100 \mathrm{~g}, \beta$-carotene levels in the second analysis were $0.3542 \mathrm{mg} / 100 \mathrm{gm}$. The levels in the third analysis were $0.3556 \mathrm{mg} / 100 \mathrm{~g}$, so that the average $\beta$-carotene content in raw jongi was obtained as much as $0.3554 \mathrm{mg} / 100 \mathrm{~g}$.

Table 2 Data results $\beta$-carotene level analysis of mature jongi

\begin{tabular}{|c|c|c|}
\hline \multirow{2}{*}{ Sample } & Until (mg/100 g) & Average rate (mg/100 g) \\
\hline \multirow{3}{*}{ Mature jongi } & 1.1870 & \\
\cline { 2 - 2 } & 1.1812 & \multirow{2}{*}{1.1841} \\
\cline { 2 - 2 } & 1.1842 & \\
\hline
\end{tabular}


$\beta$-carotene levels in the analysis of the first ripe jongi fruit were $1.1870 \mathrm{mg} / 100 \mathrm{~g}$, the $\beta$-carotene levels in the second analysis were 1.1812 , and the levels in the third analysis were 1.1842 so that the average $\beta$-carotene content in ripe jongi was obtained as much as $1.1841 \mathrm{mg} / 100 \mathrm{~g}$.

This study used a sample of jongi fruit (Dillenia Serrata Thunb.) As the object of research to analyze $\beta$-carotene levels, while the parts to be studied were raw and ripe jongi flesh. Raw and ripe jongi fruit can be distinguished based on their respective characteristics, where the raw jongi meat is white and covered by petal leaves. In contrast, in ripe jongi the flesh is dark yellow or yellow towards orange and the petals are open or blooming. So that the meat is visible, this study used UV-Vis spectrophotometry to analyze $\beta$-carotene levels quantitatively.

UV-Vis spectrophotometry is used in analyzing $\beta$-carotene levels in jongi. A study regarding $\beta$-carotene level used UVVis spectrophotometer to analyze $\beta$-carotene levels in their research, such free radical scavenging activity against DPPH (1,1-diphenyl 2-pikrilhidrazil) cantaloupe fruit extract (Cucumis melo var. cantalupensis L.) [17]. The UV-Vis spectrophotometry tool has a high degree of accuracy in analyzing a sample where this tool is a method for testing the amount of light absorbed in each wavelength in the ultraviolet area, which works by forwarding the light transmitted by blank and sample detectors [18].

The results showed that $\beta$-carotene levels were average contained in raw jongi as much as $0.3554 \mathrm{mg} / 100 \mathrm{~g}$, and the moderate $\beta$-carotene content contained in ripe jongi as much as $1.1841 \mathrm{mg} / 100 \mathrm{~g}$. It is known that the $\beta$-carotene content in ripe jongi fruit is more than the $\beta$-carotene content in raw jongi fruit. The mechanism of $\beta$-carotene formation begins with the condensation of two geranylgeranyl diphosphate (GGPP) molecules to form phytoene. The phytoene formed desaturates to produce $\zeta$-carotene, after which $\zeta$-carotene desaturates to lycopene [19]. After lycopene is formed, there is the formation of carotenoid compounds, namely $\beta$-carotene by way of lycopene $\beta$-cyclase ( $\beta$ LCY) inserting a $\beta$-ionone ring to one end of lycopene to produce $\beta$-carotene with groups of each cyclic end forming $\beta$, $\beta$ branches [20].

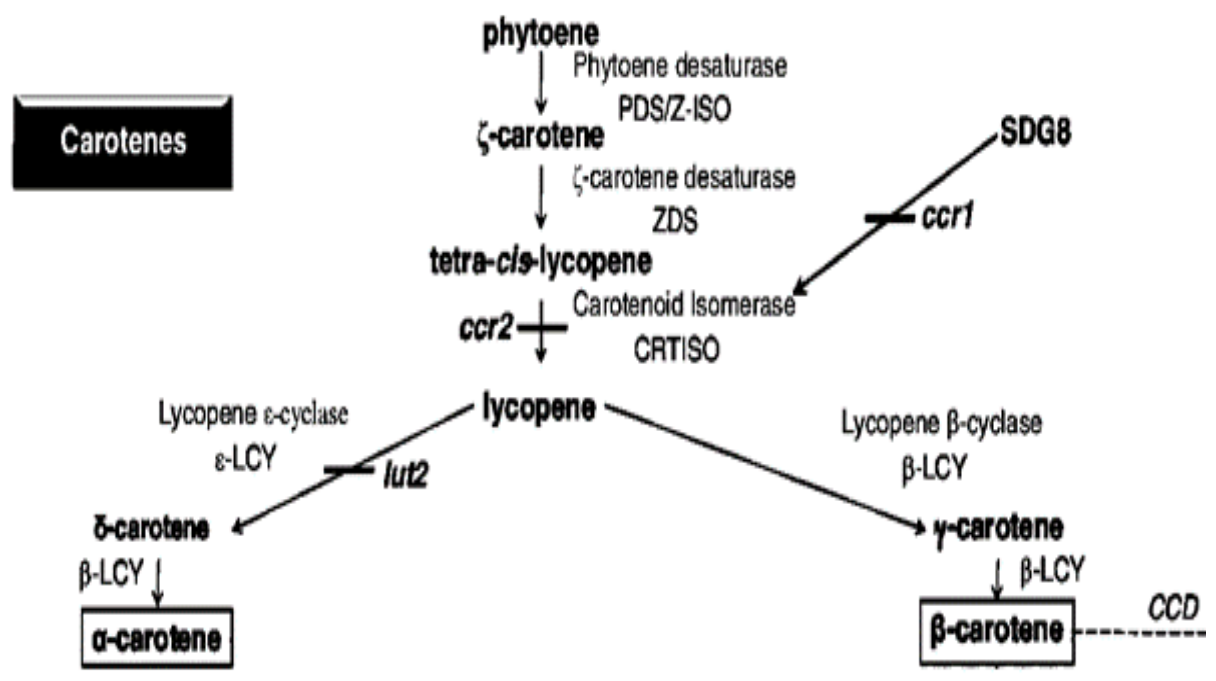

Figure 1 The mechanism of $\beta$-carotene formation in plant [19]

Based on the above mechanism, differences in $\beta$-carotene levels in raw and ripe jongi are caused by a large amount of lycopene in the jongi. The lycopene content in raw jongi is more petite than ripe jongi, so that the $\beta$-carotene produced in raw jongi is less than the $\beta$-carotene content made in ripe jongi. The amount of $\beta$-carotene content can also be affected by the process of the harvesting process. [21]. $\beta$-carotene is a yellow to the orange pigment in the fruit. The ripe jongi is dark yellow, while the raw jongi is yellowish-white. It can be seen that the ripe jongi is closer to the $\beta$-carotene color, which is said to be the darker the fruit and vegetable color leads to a reddish yellow color, the more $\beta$-carotene contentripe jongi changes color from yellowish-white to dark yellow due to the ripening process. There is a synthesis of carotenoid pigments that have existed before but have not been seen in the ripening process. When fruiting is ripe carotenoid pigments that make the fruit look yellow, this pigment is called xanthophyll [22].

The $\beta$-carotene levels in jongi are different from the $\beta$-carotene levels in carrots and also bitter melon. In carrots, the $\beta$ carotene levels are higher than the $\beta$-carotene levels in jongi. The $\beta$-carotene levels in bitter melon are lower than the levels of $\beta$-carotene in jongi. The darker the color (orange, yellow, green) in the fruit or vegetable, the higher the $\beta$ carotene content. [23]. Carrots have a thick orange color, jongi has a bright yellow color and bitter melon has a green 
color that is not too dark. For other research, namely the analysis of $\beta$-carotene levels in pumpkins, the study analyzed the $\beta$-carotene levels in yellow pumpkins with different levels of maturity. Based on the results of his research, it was found that $\beta$-carotene levels in raw pumpkins were $1,742 \mu \mathrm{g} / \mathrm{g}$, in the half-ripe pumpkin was $3,745 \mu \mathrm{g} / \mathrm{g}$ and in the ripe yellow pumpkin was $3,915 \mu \mathrm{g} / \mathrm{g}$ [24]. Compared with the $\beta$-carotene content in jongi, the $\beta$-carotene content in raw jongi is greater than the $\beta$-carotene content in yellow pumpkin.

Jongi contains $\beta$-carotene, which is relatively high. $\beta$-carotene is a provitamin $A$, which plays a role in the formation of vitamin A where one of the functions of vitamin A is to neutralize free radicals that enter the body so that the public can consume this fruit. $\beta$-carotene is also helpful to prevent cancer, various cardiovascular diseases, and cataracts [25]. The intake of dietary supplements enriched with natural $\beta$-carotene containing cis and trans stereoisomers can also control multiple disorders, including atherosclerosis, diabetes, psoriasis, and ophthalmological diseases [26].

Beta carotene may be a vitamin A forerunner (retinol) and the foremost vital of the provitamins A. It is cleaved to create two atoms of retinal, one of which is assist metabolized to make retinol and retinoic corrosive. There are three isomers of carotene, alpha, beta, and gamma, with the beta isomer being the most dynamic. Retinoids influence quality expression through atomic receptors (different retinoic corrosive receptors and retinoid X receptors) [27]. Based on their chemical structure, carotenoids can be classified as carotenes and xanthophylls. Carotenes (like $\beta$-carotene, $\alpha$ carotene, and $\beta$-kryptoxanthin) are non-oxygenated carotenoids that will be straight or have cyclic hydrocarbons at one or both closes of the particle. Moreover, a few of the carotenoids serve as antecedents of vitamin A, in this way permitting their classification in provitamin A and non-provitamin A carotenoids. Provitamin A carotenoids surrender vitamin $A$ and its metabolites (retinoids) upon enzymatic and non-enzymatic cleavage, with $\beta$-carotene being the foremost plenteous and well-characterized precursor of vitamin A [28].

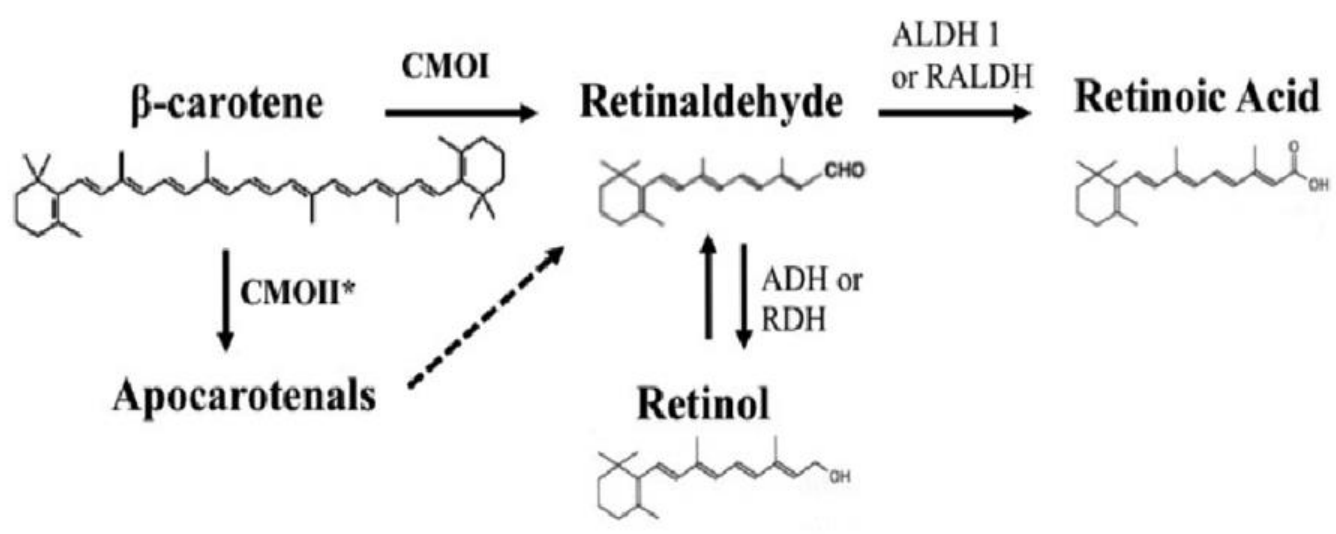

Figure 1 The outline of vitamin A formation from $\beta$-carotene by digestion system [28].

Symmetric oxidative cleavage of $\beta$-carotene at the $15,15^{\prime}$ two fold bond by the chemical $\beta$-carotene- $15,15^{\prime}$-oxygenase (CMOI or BCMO1 or BCO1) creates two atoms of retinaldehyde. Retinaldehyde can be oxidized into retinoic corrosive by individuals of the aldehyde dehydrogenase one family of proteins (ALDH 1 or RALDH). Assist oxidation of retinoic caustic by chemicals that have a place to the cytochrome P450 (CYP) 26 family changes over retinoic corrosive into more polar compounds, counting 4-oxo retinoic corrosive, which are accepted to be transcriptionally dormant. On the other hand, distinctive shapes of liquor dehydrogenase (ADH) from the MDR superfamily and an assortment of retinol dehydrogenases (RDH) from the SDR superfamily can decrease retinaldehyde to retinol [28].

\section{Conclusion}

Jongi is a source of vitamin A because it contains $\beta$-carotene. The body can convert the carotene content in red, green, yellow, and orange fruits into vitamin A. The benefits of vitamin A are significant for the body and affect vision, immunity, reproduction, and skin health, making vitamin A very important for consumption. Therefore, vitamin A is a nutrient that is vital for human health. The amount of $\beta$-carotene content obtained in raw Jongi and mature Jongi was $0.3554 \mathrm{mg} / 100 \mathrm{~g}$ and $1.1841 \mathrm{mg} / 100 \mathrm{~g}$. Although the content of $\beta$-carotene is not as high as melon orange (135 mcg), or manga (112 mcg), Jongi can be used as a source of vitamin A for public consumption to fulfill the need for vitamin A. 


\section{Compliance with ethical standards}

\section{Acknowledgments}

The authors would like to thank the Lab Assistant at Chemistry Education Laboratory Faculty of Education and Department of Biochemistry Faculty of Medicine Tadulako University for supporting and assist during the research.

\section{Disclosure of conflict of interest}

The authors declare that there is no conflict of interest regarding the main research, authorship and publication of this paper.

\section{References}

[1] Grune T, Lietz G, Palou A, Ross AC, Stahl W, Tang G, Thurnham D, Yin SA, Biesalski HK. $\beta$-Carotene is an important vitamin A source for humans. The Journal of nutrition. 2010 Dec 1;140(12):2268S-85S.

[2] Ngamwonglumlert L, Devahastin S. "Carotenoids," in Encyclopedia of Food Chemistry, Elsevier. 2019; 40-52.

[3] Tofalo R, Suzzi G. "Yeasts," in Encyclopedia of Food and Health, Elsevier. 2016; 593-599.

[4] Gul K, Tak A, Singh AK, Singh P, Yousuf B, Wani AA. Chemistry, encapsulation and health benefits of $\beta$-caroteneA review. Cogent Food \& Agriculture. 2015 Dec 31;1(1):1018696.

[5] Burri BJ. "Carotenoids: Chemistry, Sources and Physiology," in Encyclopedia of Human Nutrition, Elsevier. 2013; 283-291.

[6] Sun T, Xu Z, Wu CT, Janes M, Prinyawiwatkul W, No HK. Antioxidant activities of different colored sweet bell peppers (Capsicum annuum L.). Journal of Food Science. 2007 Mar;72(2):S98-102.

[7] Derradji-Benmeziane F, Djamai R, Cadot Y. Antioxidant capacity, total phenolic, carotenoid, and vitamin C contents of five table grape varieties from Algeria and their correlations. OENO One. 2014 Jun 30;48(2):153-62.

[8] Katzinger J, Murray MT. "Vitamin A," in Textbook of Natural Medicine, Elsevier. 2020; e2: 910-918.

[9] Pelima, J Noviana. "Potensi Buah Jongi (Dillenia Serrata Thumb) Sebagai Sumber Pangan Fungsional Berbasis Lokal : Kajian Pustaka".

[10] Hasniarti. "Studi Pembuatan Permen Buah Dengen (Dillenia Serrata Thumb.)." Skripsi, Unhas. August 2012.

[11] Wibawa AH, Sutomo S. "Potential Study of Dillenia Serrata Thunb. Fruit Extract from Bali Botanical Garden's Collection," Jun 2021; 22(2): 79-84.

[12] Tower J. "Programmed cell death in aging," Ageing Research Reviews. Sep. 2015; 23: 90-100.

[13] Ovadya Y, Krizhanovsky V."Senescent Cell Death Brings Hopes to Life," Cell Cycle. Jan 2017; 16(1): 9-10.

[14] Kalase MB, Walanda DK, Napitupulu M. "Analysis of Vitamin C and Calcium in Jongi Fruits (Dillenia Serrata Thunb) Based on Their Maturity Level," J. Akademika Kimia. Sep. 2020; 8(3): 147-152.

[15] H Stutz, N Bresgen, PM Eckl. "Analytical Tools for the Analysis of $\beta$-carotene and Its Degradation Products," Free Radical Research. May 2015; 49(5): 650-680.

[16] Zarnila Z, Napitupulu M, Jura MR. "Analisis Kadar b-Karoten Buah Pisang Raja (Musa Paradisiacal L) dan Pisang Kepok (Musa Paradisiaca Forma Typica) dengan Metode Spektrofotometri UV-Vis," J. Akad. Kim. Dec. 2018; 7(4): 164.

[17] Kusbandari A, Susanti H. "Kandungan Beta Karoten dan Aktivitas Penangkapan Radikal Bebas Terhadap Dpph (1, 1-Difenil 2-Pikrihydrazil) Ekstrak Buah Blewah (Cucumis Melo Var. Cantalupensis L) Secara Spektrofotometri Uv-Visibel," J.Pharm.Sci.Community. May 2017; 14(1): 37-42.

[18] Reule AG. Errors in spectrophotometry and calibration procedures to avoid them. Journal of research of the National Bureau of Standards. Section A, Physics and chemistry. 1976 Jul;80(4):609.

[19] Cazzonelli CL, Nisar N, Hussain D, Carmody ME, Pogson BJ. "Biosynthesis and Regulation of Carotenoids in Plants-Micronutrients, Vitamins and Health Benefits," in Plant Developmental Biology - Biotechnological Perspectives, E. C. Pua and M. R. Davey, Eds. Berlin, Heidelberg: Springer Berlin Heidelberg. 2010; 117-137. 
[20] Moise AR, Al-Babili S, Wurtzel ET. "Mechanistic Aspects of Carotenoid Biosynthesis," Chem. Rev. Jan. 2014; 114(1): 164-193.

[21] Pénicaud C, Achir N, Dhuique-Mayer C, Dornier M, Bohuon P. "Degradation of B-Carotene During Fruit and Vegetable Processing Or Storage: Reaction Mechanisms and Kinetic Aspects: A Review," Fruits. Nov. 2011; 66(6): 417-440.

[22] Khoo HE, Prasad KN, Kong KW, Jiang Y, Ismail A. Carotenoids and their isomers: color pigments in fruits and vegetables. Molecules. $2011 \mathrm{Feb} ; 16(2): 1710-38$.

[23] De Pee S, West CE, Permaesih D, Martuti S, Hautvast JG. Orange fruit is more effective than are dark-green, leafy vegetables in increasing serum concentrations of retinol and beta-carotene in schoolchildren in Indonesia. The American journal of clinical nutrition. 1998 Nov 1;68(5):1058-67.

[24] Kulczyński B, Gramza-Michałowska A. The profile of carotenoids and other bioactive molecules in various pumpkin fruits (Cucurbita maxima Duchesne) cultivars. Molecules. 2019 Jan;24(18):3212.

[25] Basu HN, Vecchio AJ, Flider F, Orthoeter FT. Nutritional and potential disease prevention properties of carotenoids. Journal of the American Oil Chemists' Society. 2001 Jul;78(7):665-75.

[26] Xu Y, Ibrahim IM, Wosu CI, Ben-Amotz A, Harvey PJ. Potential of new isolates of Dunaliella salina for natural $\beta$ carotene production. Biology. 2018 Mar;7(1):14.

[27] Clark S. "Beta Carotene," in xPharm: The Comprehensive Pharmacology Reference, Elsevier. 2007; 1-3.

[28] Shete V, Quadro L. "Mammalian Metabolism of $\beta$-Carotene: Gaps in Knowledge," Nutrients. Nov 2013; 5(12): $4849-4868$. 